\title{
Grassroots waste picker organizations addressing the UN sustainable development goals
}

\author{
Jutta Gutberlet \\ University of Victoria, Department of Geography, PO BOX 3060 STN CSC, Victoria, B.C. V8W 3R4, Canada
}

\section{A R T I C L E I N F O}

\section{Article history:}

Accepted 14 September 2020

\section{Keywords:}

Waste pickers

Social and Solidarity Economy

Recycling

SDGs

Waste governance

Global South

\begin{abstract}
A B S T R A C T
Worldwide waste pickers work under deplorable conditions and are not recognized for their environmental and community services, by recovering and diverting recyclable materials from waste. Brazil has accumulated experiences of international relevance, particularly between 2004 and 2015, due to institutional and policy support for the Social and Solidarity Economy and the creation of a National Waste Pickers' movement. These conditions have favored the formation of new recycling cooperatives throughout the country. While there is still a wide spectrum of differences among these membershipbased organizations, they also have many characteristics in common and share similar values and objectives. This research aims to demonstrate that when organized and supported by public policies and inclusive governance these groups are able to tackle several of the UN Sustainable Development Goals (SDGs). This article presents results of a case study, conducted over the period of 5 months in 2018, involving 21 waste picker cooperatives in the metropolitan region of São Paulo, Brazil. Data collection included the application of a questionnaire to the leaders of the 21 cooperatives and site visits to their facilities, including informal conversations with members. Data was collected at the cooperatives and involved note taking and voice recording. The data was transcribed and tabled for the subsequent content analysis. The results demonstrate the impacts of the work of organized waste pickers on SDGs (goals \# 1, 5, 8, 11 and 12). The study shows how these groups address social, economic and environmental targets, how they build resilience and reduce vulnerabilities. Many cooperatives still operate under precarious conditions, suffering from weak government commitments and neglect or from the volatility of the economy. Public policies and participation in governance are instrumental in acknowledging waste picker organizations and remunerating their services to thus unlock their full potential to further the progress on the implementation of SDGs. Political will is paramount for waste pickers to become the champions in the transition to more sustainable development.
\end{abstract}

(ㄷ) 2020 Elsevier Ltd. All rights reserved.

\section{Introduction}

Globally, more than 22 million waste pickers work in the informal sector. They earn a living by collecting recyclable household waste at landfills, waste dumps or in streets and sell the reclaimed materials to recycling shops, intermediaries or middlemen (Kaza, Yao, Bhada-Tata, \& Woerden, 2018). The informal sector embodies a broad spectrum of officially unrecognized activities, particularly in the service sector. Because it is unregulated and slips the control and tax revenue of governments, the informal sector is sometimes met with hostile urban governance policies, negatively affecting these workers (Nzeadibe, 2015, Chap. 5). In the global South, the informal sector -as will be demonstrated for the case of waste

E-mail address: gutber@uvic.ca pickers- generates vital goods and services with broad implications for urban livelihoods and overall environmental sustainability.

Most waste pickers work under precarious, risky and unhealthy conditions (Binion \& Gutberlet, 2012; Gutberlet \& Uddin, 2018; Omotoso, 2017). They suffer from stigma attached to informal work and the lack of recognition for the services provided. Their earnings fluctuate, depending on global price variations and the intermediaries who determine the prices (Ezeah, Fazakerley, \& Roberts, 2013; Wilson, Rodic, Scheinberg, Velis, \& Alabaster, 2012). Some waste pickers form member-based organizations (MBOs) like cooperatives, associations, (Dias \& Samson, 2016; Gutberlet, 2015; Oliveira Dias, 2019), networks (Routh, 2014), unions (Bhaskar \& Chikarmane, 2012), or small enterprises (Gutberlet et al., 2016). These organizations provide a kind of social safety net (O'Hare, 2020), helping them to better absorb shocks (Ogando, Roever, \& Rogan, 2017) and to create opportunities to 
improve their livelihoods (Meira, Dutra, Yamane, \& Siman, 2020). Cooperatives aim to be "people-centered enterprises owned, controlled and run by and for their members to realize their common economic, social, and cultural needs and aspirations" (International Co-operative Alliance, 2018, p. 1).

Cooperatives are considered part of the Social and Solidarity Economy (SSE), a broad theoretical and plural concept that covers diverse economic models and approaches based on social objectives, socially inspired work organizations, shared core values such as redistribution of resources, reciprocity, solidarity practices and self-management (Moulaert \& Ailenei, 2005). SSE initiatives strive for collaborative work and business ethics (Moulaert \& Nussbaumer, 2005). In several parts of the world policies have been developed that recognize the important role of communitydriven and citizen-led social economy organizations which address poverty and exclusion (Utting, 2017). SSE takes a different approach to informal and non-standard forms of employment. It focuses on integrating informal workers and strengthening member-based organizations, recognizing the risk of exploitation, the specific vulnerabilities and the challenges that shape this sector.

Despite the favorable policies that have supported waste picker MBOs in several countries, large structural differences between these groups still exist, e.g. in terms of leadership skills, availability of space, infrastructure and equipment, internal governance, levels of formal support, and ability to establish contracts with governments or private companies. These disparities affect their working conditions, productivity, income and ultimately their ability to address some of the Sustainable Development Goals (SDGs). In 2015, the UN General Assembly adopted a resolution, agreeing to the SDGs -a set of 17 universal, overarching and interdependent transformative goals with 169 targets- to address key issues such as poverty, hunger, gender inequity, resource degradation and environmental contamination, to achieve a more just, equitable and sustainable world. However, the SDGs are a contested political agenda, too often dominated by technocratic, top down decision making and missing out on community-produced knowledge and the inclusion of the most-marginalized actors. (Weber, 2017),

Waste pickers reclaim resources (Siman, et al. 2020; Murakami, Sulzbach, Pereira, Borchardt, \& Sellitto, 2015), diverting them into the circular economy (Gutberlet, Carenzo, Kain, and de Azevedo, 2017a). They co-produce city services, particularly in low-income residential areas where no formal waste collection would otherwise happen (Fahmi \& Sutton, 2010; Mitlin, 2008). The activity provides jobs and tackles the growing urban unemployment in the global South (ILO, 2018; Jaligot, Wilson, Cheeseman, Shaker, \& Stretz, 2016). Many of these benefits fall under the SDGs. This paper aims to discuss how organized waste pickers can contribute to SDGs and why grassroots organizations are crucial in tackling SDGs. What are the challenges these organizations face and what are the strategies and actions available to them to address the difficulties?

The article reviews the main theoretical arguments related to the role of SSE organizations (such as waste picker cooperatives) and supportive public policies in building sustainable communities and addressing SDGs. This discussion is supported by social and environmental justice theory, to fully acknowledge the exploitation and injustices committed against the poor and against the environment that can be rectified by supporting SSE organizations. The article argues for concrete actions and policies oriented toward strengthening MBOs, redistributing resources and power, as well as enabling these organizations to address SDGs. The theoretical frame applied to analyze and better understand the contributions of the informal sector and specifically waste pickers to SDGs is based on overlapping, hybrid social and environmental justice theory (decent work, fair pay, empowerment, environmental services etc.) and sustainable livelihood approaches (poverty reduction, inclusion, gender equity, etc.). The author does not come from a deficit-based framing of informal work, but supports diverse ways of co-producing waste management with organized waste pickers (Mitlin, 2008; Moretto, Faldi, Ranzato, Rosati, \& Boozi, 2018).

The empirical evidence in this article stems from the review of the current literature as well as from research conducted in the metropolitan region of São Paulo (MRSP), in Brazil, one of the largest urban agglomerations in the world, with 21.6 million inhabitants, spread over 39 municipalities (including the state capital São Paulo with 12.2 million inhabitants, in 2018), covering an area of $7947 \mathrm{~km}^{2}$ (EMPLASA, 2018). Rapid urban growth, particularly since the 1970s has resulted in uneven spatial distribution of the population and significant socio-economic disparities, reflecting in social injustices, e.g. the precarious provision of essential public services and infrastructure in the urban periphery.

The research was conducted in 2018, involving visits to 21 waste picker cooperatives from the MRSP and the application of a questionnaire, generating mostly qualitative data. The data analysis involved theme coding and content analysis (Schreier, 2012) focusing on the ways in which waste picker cooperatives contribute to the SDGs and the everyday hurdles they are facing. The literature defends the argument that waste picker organizations can create and preserve employment, facilitate the entry of women into the work force and integrate disadvantaged workers (Besen, Ribeiro, Gunther, \& Jacobi, 2014; Dias, 2002; Dutra, Yamane, \& Siman, 2018; Gerometta, Haussermann, \& Longo, 2005; Siman et al., 2020). The Brazilian SSE experience, supported by relevant public policies, provides an example of global relevance for transitioning from informal to formal employment.

The next section introduces the SSE policy background which has enabled the expansion of waste picker organizations in Brazil. Developments between 2003 and 2016 have distinguished Brazil internationally, with its community-driven, grassroots social innovations, targeting SDGs. The article provides a detailed description of the research methodology, followed by the discussion of the main findings, addressing the research question centered on how organized waste pickers are able to localize SDGs. The discussion focuses primarily on the economic (SDG 1, SDG 8), social (SDG 5) and environmental goals (SGD 11, SDG 12). The final section summarizes the prerequisites required for waste picker organization, local governments and communities to progress their local SDGs agendas, highlighting specifically the role of waste pickers. Some findings can be generalized and also apply to waste pickers in other geographic contexts.

\section{Brazil's social and solidarity economy and socio-productive inclusion of waste pickers}

Differently to many hostile urban governance policies that hinder and ban the activities of waste pickers, Brazil's SSE has promoted measures to generate livelihood opportunities to combat poverty and to integrate waste pickers. Over the past two decades, specifically under President Luiz Inácio Lula da Silva (2003-2011) and President Dilma Rousseff (2011-2016), several legislations and public policies have facilitated the inclusion of waste picker cooperatives in waste management. Brazil is the first country to recognize the profession 'waste picker', when in 2002, the Ministry of Labor and Employment (Ministério de Trabalho e Emprego, MTE) created the professional category: catador, described as 'collector of recyclable materials', to be included in the Brazilian classification of occupations (Classificação Brasileira de Ocupações, Code 5192-05). As per federal decree (No. 5940, October 2006) public institutions (offices, schools, banks, hospitals, public enterprises) are required to separate and donate the recyclable fraction 
of their garbage to recycling associations and cooperatives. This represents an important step of directing resources towards waste pickers.

The National Policy on Basic Sanitation (Federal Law No. 11,445, January 5th, 2007) (Brazil, 2007) includes solid waste as part of sanitation and authorizes municipalities to hire recycling cooperatives and associations to collect, process and market recyclable or reusable municipal solid waste. Both legislations have allowed waste picker groups to access new funding opportunities and to participate in formal recycling programs. Furthermore, federal law No. 12,017 (August 12th, 2009), which changes the law of budget guidelines, allows the direct transfer of resources to cooperatives, without intermediation of municipalities or social organizations of public interest. This new arrangement gives waste picker organizations greater autonomy.

Most influential, however, is the National Solid Waste legislation (Política Nacional de Resíduos Sólidos PNRS) (Federal Law No. 12,305, August 2nd, 2010), a result of government, private institutions, non-governmental organizations, and civil society, bringing together principles, objectives, instruments and guidelines for solid waste management (Brazil, 2010). The law prescribes the compliance with the principles of prevention and precaution (reduction, reuse and recycling), in addition to the application of environmentally appropriate final solid waste destination methods. The PNRS proposes shared responsibility for the product life cycle and the reduction of negative human and environmental health impacts throughout the life of products. It further makes a strong case for implementing selective waste collection of reusable and recyclable materials with the inclusion of waste pickers (catadores), recognizing the fact that reusable and recyclable materials are economic goods, also of social value, that generate work and income (Dagnino \& Johansen, 2017). The law encourages municipalities to hire cooperatives for selective waste collection and promotes studies and research on waste related topics.

The Inter-ministerial Committee of the Brazilian Solid Waste Policy and the Steering Committee for the Implementation of Reverse Logistics were also created under this law. With the addition of Decree 7404 (December 23rd, 2010), a last-minute alteration was made, allowing for waste incineration, previously not permitted under the PNRS, which impacts recycling programs and livelihoods (Demaria \& Schindler, 2016; Gutberlet, Bramryd, \& Johansson, 2020).

In parallel with the advances in waste management legislation, Brazil has also developed its Social and Solidarity Economy (SSE), since the early 2000s. The SSE marks an alternative path to the exploitive, competitive and commodified social relationships and work relations that characterize capitalism (Silva \& Carvalho Filho, 2018). In 2003, the federal Government created the National Secretary of Solidarity Economy (Secretaria Nacional de Economia Solidária, SENAES) under the Ministry of Work and Employment, inserting Solidarity Economy into the national public policy sphere. During the same year, the Brazilian Forum of Solidarity Economy (Fórum Brasileiro de Economia Solidária, FBES) was constituted to articulate and mobilize the Solidarity Economy within the country and to maintain a dialogue with the Government. SENAES has actively supported forms of production that are based on collective and cooperative principles, setting the conditions for nation-wide "solidarity recycling" programs with over 900 member-based waste picker organizations. As highlighted by Marques, the SSE describes a new form of economic development where "the main protagonists [...] are the workers, seen as historical subjects in social transformation, defending in a militant way a new mode of production and wealth distribution. Self-management and the productive character are essential features of the initiatives" (Marques (2014), p. 5).

Waste pickers are important protagonists of the SSE. Their organizations value autonomy and self-determination (Britschgy,
2018). The goal of waste picker cooperatives is to work collectively, establish democratic deliberations and to seek the emancipation and inclusion of waste pickers. These organizations and the livelihoods behind them are complex and contradictory, combining the individual and the communal; competition and collaboration; autonomy and dependency.

First struggles for inclusion and recognition in policy making involved the National Waste Picker's Movement (Movimento Nacional dos Catadores de Materiais Reciclaveis, MNCR), a central voice for waste pickers. Organized civil society plays a prominent participatory role in governance, pushing forward counterhegemonic projects, which might generate disagreement and opposition (Jacobi \& Dias Perez, 2016; Luckin \& Sharp, 2004). Conflicts and antagonisms are constitutive of 'the political' while the neoliberal consensus system overlooks the fundamental cause of inequality (Randolph \& Frey, 2019). Creating spaces for political dialogue is essential for more inclusive and participatory governance.

The transversal character of Brazil's SSE has enabled other government actors, such as the Ministry for Social Development (Ministério de Desenvolvimento Social, MDS), to backup intersectoral collaborations supporting social inclusion projects, which has also benefited waste pickers. Democratic spaces were created since 2006; such as the National Council for Solidarity Economy, who was then in charge of organizing National SSE conferences (Schiochet, 2012). "Economy is not one "natural" thing; it is always plural and socially constructed" (Laville, 2013, 1). Creating communication channels and knowledge transfer opportunities are thus essential for a plural economy to thrive, allowing for a paradigm shift and the transition towards socio-productive inclusion. In 2009, the 1st conference aimed at mobilizing and organizing popular participation in the SSE took place. In 2010, the 2nd national conference was dedicated to the right to work and live in cooperation in a sustainable way and in 2014, the 3rd national conference focused on consolidating the national plan to strengthen the SSE in Brazil (Nacional, 2015).

Since 2008, SENAES has also narrowed the relations with the National Waste Pickers' Movement (MNCR) who was able to capture significant amounts of funding for waste picker associations and cooperatives (e.g. in 2008, with the SENAES Urban Solid Waste Program - Programa Resíduos Sólidos Urbanos). These programs have helped organize more waste pickers into cooperatives and associations. The Federal Decree No. 7405 (23rd, December 2010) institutes the 'Pro-Catador' program, creating a joint interministerial Committee for social and economic inclusion of waste pickers (Comitê Interministerial para Inclusão Social e Econômica dos Catadores de Materiais Reutilizáveis e Recicláveis, CIISC), which has been fundamental to the rising of the category (Carvalho \& Rodini, 2017). Between 2008 and 2018, the SENAES has invested a total of 887 million Reais in Solidarity Economy programs, of which $32 \%$ has directly benefitted waste picker activities (Britschgy, 2018). The funding peaked between 2012 and 2015, and has receded since then. With the political crisis under the government of Dilma Rousseff (2015-2016) and her impeachment in August 2016, the SSE gradually lost political influence and support in Brazil. The subsequent neoliberal president Temer (2016-2018) cut the funding and reduced SENAES to a sub-secretary which in 2018 was completely dismantled, shortly after the election of Jair Bolsonaro. Brazil currently experiences extremely adverse conditions related to public policies aiming at socio-economic inclusion. The SSE which had once flourished and transformed the country over the previous 10 years, unfolding into a highly relevant international example for socio-productive inclusion, was rapidly destroyed over the course of one year, overall debilitating the social state and increasing social and economic inequality and poverty within the country. 


\section{Research methodology}

This research builds on long-term Community-Based Research (CBR) with waste pickers in the metropolitan region of São Paulo. $\mathrm{CBR}$ recognizes that academia is not the only domain of knowledge building. It relies on strong relationships with community members and the establishment of partnerships with research participants which actively engage in knowledge creation processes (Kovach, 2009). CBR acknowledges multiple sources and ways of generating learning, including traditional and indigenous epistemologies (Clement, 2019; Howard, 2016). CBR seeks diverse voices, equitable and collaborative relationships with research participants and supports empowering relations benefiting the individual and the partnership levels (Hutchinson \& Lovell, 2013). Successful partnerships between researchers and community members are those where the partners' primary interests or needs are met, organizational capacities are increased, and where partners adopt shared, long-range social change perspectives (Strand, Marullo, Cutforth, Stoeker, \& Donohue, 2003). The author has an ongoing relationship with leaders of waste picker organizations in the region and keeps an active facebook account linked to the project Mapping Waste governance to communicate and to disseminate research results among the waste pickers.

This study builds on research conducted since 2005 with waste picker cooperatives in the region, which allowed me to build trust and collaboration. My experiences of living and working in Brazil allows for contextualized interpretations regarding local solid waste systems, recycling value chains and the organization of waste pickers. Ethical approval for the empirical work was obtained in June 2017 from the Human Research Ethics Board at the University of Victoria (Protocol 17-193).

The present study was conducted over five months (from August to December 2018), involving leaders of 21 waste picker organizations (20 cooperatives and 1 association). The selection of the research participants was based on previous contacts with some waste picker groups and was then expanded, through snowballing. Recruitment stopped with the saturation of the answers, reflecting a large spectrum of structural differences between the groups, covering large and/or well-equipped groups as well as those that were small in membership or operating with the bare minimum equipment. The 21 groups included in the study repre- sent the geographic diversity in the region and captures political differences between municipalities (Table 1).

The fieldwork was conducted with the support of a Brazilian research assistant (Solange Dias), who is well familiarized with the research topic and research participants, which facilitated recruitment and the logistics of the visits. Each visit took between two to three hours. Due to the large distances between the locations and the heavy traffic in the region, we could only visit one group per day. The questionnaire was applied to the group leaders. The answers were voice recorded and additional notes were taken during the informal conversations. The questionnaire covered the following themes: (a) background, origin of the group and level of external support received; (b) socio-economic and demographic characterization of the group members; (c) internal recruitment policies for new members and internal governance structure; (d) gender and positions occupied in the cooperative; (e) types of services provided to the community, businesses and local government; (f) level of infrastructure available in the cooperative; (g) occupational health situation and protection; and (h) access to training and capacity-building.

We also visited the operating spaces and had informal conversations with other group members. The conversations allowed for the participants to expand on their perceptions of the cooperative's contributions to the SDGs. Sometimes other members of the cooperative administration joined the conversations with the group leaders. Follow-up conversations were held through phone, Email and WhatsApp to collect further details, to complement the data set and to validate the research findings and reflections. A one-day workshop was organized in December 2018, at the Federal University of the $A B C$, where the results were presented and discussed with representatives from the 21 groups. They complement the information and validated the findings.

The manually registered questionnaire data was transferred to an Excel spreadsheet. The taped questionnaire application was partially transcribed and exported to Excel, complementing the data set. Only the information relevant to the research questions was used for the qualitative interpretation. Quantitative, but mostly qualitative content analysis and visualization of the results followed, with thematic coding, allowing for inferences on the main research questions (Schreier, 2012). The conversations during the site visits explored complementary issues related to assets and

Table 1

List of cooperatives that participated in the study.

\begin{tabular}{|c|c|c|c|c|c|}
\hline Name of cooperative & City & Date of formalization & Total number of members & Women & Men \\
\hline Coopernova & Cotia & 2008 & 43 & 26 & 17 \\
\hline Cooperlimpa & Diadema & 1999 & 18 & 8 & 10 \\
\hline Coopercata & Mauá & 2012 & 27 & 14 & 13 \\
\hline Cooperpires & Ribeirão Pires & 2005 & 19 & 11 & 8 \\
\hline Cooperativa de agentes ambientais Mãos Dados & Ribeirão Preto & 2008 & 39 & 27 & 12 \\
\hline Avemare & Santana de Parnaiba & 2006 & 82 & 50 & 32 \\
\hline Cidade Limpa & Santo André & 2000 & 48 & 30 & 18 \\
\hline Reluz & São Bernardo do Campo & 2016 & 41 & 21 & 20 \\
\hline Cooperalfa & São José dos Campos & 2015 & 18 & 8 & 10 \\
\hline Coopertech & São José dos Campos & 2015 & 9 & 3 & 6 \\
\hline Futura & São José dos Campos & 2005 & 42 & 32 & 10 \\
\hline Cooperparelheiros & São Paulo - Parelheiros & 2016 & 13 & 8 & 5 \\
\hline Coopercral & São Paulo - Parelheiros & 2005 & 6 & 5 & 1 \\
\hline Cooperação & São Paulo - Vila Leopoldina & 2003 & 48 & 33 & 15 \\
\hline Associacao Nova Glicerio & Sao Paulo - Cento & 2013 & 115 & 47 & 68 \\
\hline COOPERE & São Paulo - Centro & 2003 & 72 & 40 & 32 \\
\hline Cooperglicério & São Paulo - Centro & 2006 & 33 & 10 & 23 \\
\hline Coopercaps & Sao Paulo - Interlagos & 2003 & 128 & 66 & 62 \\
\hline Coopamare & São Paulo - Sumaré & 1989 & 23 & 15 & 8 \\
\hline CORESO & Sorocaba & 2000 & 41 & 18 & 23 \\
\hline Divisao Polimeros da Rede Cata Vida & Sorocaba & 2012 & 8 & 2 & 6 \\
\hline Total & & & 873 & 474 & 399 \\
\hline
\end{tabular}


barriers as well as ways and strategies to address these issues. The following section discusses the interpretation of the empirical results in the context of the academic literature.

\section{The work of waste pickers intersecting with the UN SDGs}

The newly adopted 2030 Agenda for Sustainable Development presents 17 Sustainable Development Goals (SDGs) addressing sustainability transitions (Gupta \& Vegelin, 2016; Le Blanc, 2015). Waste is a central topic in moving towards more sustainable cities and waste pickers are important protagonists. There are over 20 million informal waste workers worldwide, with very low income, often living below the poverty line (ILO, 2012). For Latin America and the Caribbean, the estimate is around 3.8 million waste pickers, most of them informal (Terraza \& Sturzenegger, 2010). Waste pickers are among the most vulnerable and disadvantaged group in society. In Brazil, the majority (66.1\%) is Afro-descendant and a significant part (20.5\%) is illiterate or had completed only basic education (24.6\%) (IBGE, 2012). The following Table 2 summarizes key research results regarding the contributions waste picker make to specific SDGs. These key points will be discussed in detail in the following sub-sections.

In the following subsections a hybrid theoretical framework will be used to discuss the empirical data, demonstrating how the work of MBOs provides livelihood opportunities and addresses social and environmental justice issues which can be translated into five of the SDGs.

\subsection{Productive employment and decent work (SDG 8)}

Lack of decent work corrodes the well-being of the present and future society. The International Labor Organization (ILO) has contributed to the understanding and recognition of the multifaceted actors, activities, and contexts in the informal economy, endorsing the strive for decent work, defined as “... productive work for women and men in conditions of freedom, equity, security and human dignity. Decent work involves opportunities for work that is productive and delivers a fair income; provides security in the workplace and social protection for workers and their families; offers better prospects for personal development and encourages social integration; gives people the freedom to express their concerns, to organize and to participate in decisions that affect their lives; and guarantees equal opportunities and equal treatment for all" (ILO, 2008, p. VI). Decent work is a multilayered concept that should reach beyond the goal of providing decent income and decent working conditions. The concept should address the phenomena of 'accumulation by dispossession', so widespread among the poor (Harvey, 2004; Samson, 2015). A critical perspective is justified since providing decent work to some can cause oppression, exclusion and exposure to human and environmental harm for others (Pulido, 2017; Melamed, 2015).

The target 'decent and full productive work' is framed under SDG 8; translated into employment creation, enterprise development, social protection, safety standards, rights at work and a governance structure that fosters social dialogue. Decent work is not necessarily achieved through formal work or the formalization of the informal sector, but rather demands pro-poor policies; targeting poverty reduction by resourcing grassroots organizations, expanding opportunities for education and building capacity and spaces for negotiations (Tucker \& Anantharaman, 2020). Foremost, the discussion requires the recognition that the formal and the informal are deeply interdependent and intertwined, with informal workers, generating indispensable goods and services (Moser, 1978).

Unemployment is a global challenge, particularly in countries of the global South, with rapidly growing populations. Brazil, a transition economy with a large urban population, has high youth unemployment (age 15-24 neither in school nor in formal work), high female unemployment and joblessness concentrated mostly among African descendent individuals (IBGE, 2009). The map of violence for Brazil also illustrates that the highest rate of homicides falls between young, black men (IPEA, 2020; Waiselfisz, 2012).

The ILO recognizes that youth employment is particularly strategic on the public policy agenda, given its importance to producing social cohesion and safeguarding the wellbeing of the people (ECLAC and ILO, 2012). In order to move towards decent work, the ILO has developed a framework of 'seven essential securities', which are often refused to informal workers (2002). These seven securities are labour market security (ensured by macroeconomic

Table 2

SDGs and links to the work of waste pickers.

\begin{tabular}{|c|c|c|c|}
\hline SDG & SDG Theme & SDG Focus & $\begin{array}{l}\text { Links to grassroots member-based organizations (MBOs) and waste } \\
\text { picker networks (WPNs) }\end{array}$ \\
\hline Goal 1 & No Poverty & $\begin{array}{l}\text { Economic growth must be inclusive to provide } \\
\text { sustainable jobs and promote equality. }\end{array}$ & $\begin{array}{l}\text { MBOs provide income and opportunities for social inclusion and } \\
\text { human development. WPNs provide capacity building and skill } \\
\text { development to expand income opportunities. }\end{array}$ \\
\hline Goal 5 & Gender Equality & $\begin{array}{l}\text { Gender equality is not only a fundamental human right, } \\
\text { but a necessary foundation for a peaceful, prosperous and } \\
\text { sustainable world. }\end{array}$ & $\begin{array}{l}\text { Women are the majority of the waste pickers working in MBOs. } \\
\text { Women have an equal job opportunity in MBOs and participate to a } \\
\text { large extent in the leadership and decision making of MBOs. } \\
\text { Cooperatives are more flexible and solidary in accommodating } \\
\text { women's special needs (e.g. child care, health) }\end{array}$ \\
\hline Goal 8 & $\begin{array}{l}\text { Decent Work and } \\
\text { Economic Growth }\end{array}$ & $\begin{array}{l}\text { Sustainable economic growth will require societies to } \\
\text { create the conditions that allow people to have quality } \\
\text { jobs. }\end{array}$ & $\begin{array}{l}\text { MBOs offer better working conditions, following labor laws and } \\
\text { health regulations; adding to economic growth. WPNs help MBOs to } \\
\text { improve their working conditions and outcomes (work flow } \\
\text { organization, work efficiency and effectiveness, health and safety at } \\
\text { work). }\end{array}$ \\
\hline Goal 11 & $\begin{array}{l}\text { Sustainable Cities and } \\
\text { Communities }\end{array}$ & $\begin{array}{l}\text { There needs to be a future in which cities provide } \\
\text { opportunities for all, with access to basic services, energy, } \\
\text { housing, transportation and more. }\end{array}$ & $\begin{array}{l}\text { Recycling services provided by waste pickers make cities more } \\
\text { sustainable (less waste, reducing the risk of water logging and } \\
\text { flooding). Cooperatives promote citizenship building, social } \\
\text { inclusion, de-stigmatization, increased self-esteem and community } \\
\text { building; making cities more resilient. }\end{array}$ \\
\hline Goal 12 & $\begin{array}{l}\text { Responsible Production } \\
\text { and Consumption }\end{array}$ & Promote responsible production and consumption. & $\begin{array}{l}\text { Waste picker MBOs educate the public on the 3Rs. WPNs participate } \\
\text { in different city forums, contributing with ideas and experiences in } \\
\text { waste management. The national waste pickers' movement is active } \\
\text { in discussions on responsible production and consumption (reverse } \\
\text { logistics and extended producer responsibility). }\end{array}$ \\
\hline
\end{tabular}


policies); employment security (employment stability); job security (opportunity to develop a "career"); work security (protection against accidents and illness at work); skill reproduction security (opportunities to gain and retain skills); income security (adequate income); and representation security (representation through independent trade unions and employers' organizations, for example) (ILO, 2002). Applied to the general working conditions of waste pickers, this framework highlights major deficiencies as well as achievements (ILO, 2019). Organizing, recognizing and integrating waste pickers in formal waste management is key to achieving these essential securities.

Waste picker cooperatives strive to be autonomous and participatory organizations, guided by values of self-help, selfresponsibility, democracy, equality, equity and solidarity; similar to principles described for the SSE (Rossi, 2018). However, these organizations are complex and contradictory and should not be romanticized. Gago (2017) has shown how neoliberalism from below can impact informal market vendors in Buenos Aires, Argentina. MBOs are not immune against structural problems such as lack of transparency, lack of democratic participation or ineffective governance, characterizing what has been termed a 'false cooperative' (Felipone, 2010). In the current study, all interviewees from the 21 organizations expressed the importance of participatory governance (e.g. autogestão), democratic practices and social inclusion for their groups. The results show that cooperatives, in general, emphasize job security, improved working conditions, fair wages, collaboration with other groups and enhanced service provision in their communities.

Decent work for waste pickers includes regulated working hours and rest periods, social and health benefits as well as access to washrooms, running water, kitchen or refectory. The majority, except for two groups, had access to washrooms, running water and kitchen space or a refectory; providing the workers with basic sanitary conditions. All groups had established working hours and rest periods, as well as access to social and health benefits. The majority (16 groups) had access to Personal Protective Equipment (PPE), however, four of these groups did not use the equipment at that time; while another five did not have any PPE. In terms of equipment, all groups had at least one weight scale and except for three groups, everybody had at least one press. Nine of the 21 groups used tables to separate the material and the rest worked at moving belts. Many of the infrastructural improvements were achieved with the support of specific funding programs for community-based social enterprises and cooperatives under Brazil's SSE (Caruana \& Srnec, 2013).

Most groups had a low turnaround, with members staying at least one to three years and more in the cooperative; only four groups seem to have a high turnover in membership. One of the leaders explained: "today, turnover is low because income conditions are good and there is good equipment (specifically the belt). During the last 2 years no one has left. Usually, when the income falls that is when people leave".

In most groups, members were frequently exposed to capacity building activities, except in six groups where members had not yet received any training. All groups confirmed that peer-to peer learning is the norm. Ten groups mentioned to have participated recently in training on cooperativismo; the Brazilian term for learning about the different ways in which cooperatives operate. Other courses frequently mentioned were about reverse logistics, selective waste collection, leadership and conflict resolution, health and safety and computer skills. Capacity building is offered through MNCR, SENAES, NGOs and university groups.

Applying the aforementioned ILO (International Labour Organization) (2002) lens on the seven securities underscores the importance of a national SSE strategy, as pursued by the Brazilian government until 2016, particularly in order to increase labour market security and to further enhance job security. Specific funding available to waste pickers through the SENAES under the previous Governments (e.g. the Pro-Catador programs) were aimed at increasing work security and skill reproduction security. Working in MBOs has improved the working conditions and has created opportunities to expand the workers' rights for decent work. The aspect income security will be discussed in the next section.

\subsection{Eradicating extreme poverty (SDG 1)}

There is a close link between SDG 1 and the objective of fomenting productive employment and decent work. The income of waste pickers depends on many factors including location, access to infrastructure and technology, quantity and quality of materials collected, government support, connections to the recycling chain as well as degree of organization and collective commercialization. The country Minimum Salary in 2018 was US\$ 249 (R\$954). Eleven cooperatives earned slightly over one Minimum Salary, two received over two Minimum Salaries and five still made less than one Minimum Salary per month.

Ten out of the 21 cooperatives were able to establish a contract either with industries or with the municipality for the service of selective waste collection. The payments made by the municipality varied between US\$ 150 and US\$200 per ton of recycled material, while some of the groups only received US\$ 60 per ton of material collected and separated. These values are usually based on landfill tipping fees, reflecting the saved expenses by the municipality. Remuneration is the result of the waste pickers' negotiation power and the level of local political will. Most groups mentioned the importance of regional networks (2nd degree cooperatives) to their negotiations with governments. Waste picker cooperatives struggle persistently to be integrated in the municipal recycling program and it is not a given that contracts are maintained when governments shift. Those waste picker organizations that had established partnerships with the city were also able to improve their working conditions on top of earning more. Having a contract with a municipality signifies more income security. Without public policy and political support that guarantees fair service payment, the aim of eradicating poverty will not be reached. In addition to income security, the ILO (2002) underlines the necessity for representation security for decent work conditions. Strong representation by the MNCR or regional networks empowers the waste pickers to negotiate contracts with the Government. The waste pickers have developed more and stronger network representations. The 2010 census identified 387,910 waste pickers, of which 38.6 were organized in groups (IPEA, 2013). The majority (42\%) work in the Southeast of the country, particularly in the state of São Paulo (79,770 waste pickers) (Dagnino \& Johansen, 2017). There are 95 waste picker organizations, 6 waste picker networks and one waste picker federation in the metropolitan region of São Paulo. The largest number of groups (46) are located in the city of São Paulo (MNCR, 2012).

Several international agencies, including the United Nations, the International Labor Organization, and the International Cooperative Alliance, have declared that "the cooperative enterprise is the type of organization that best meets all dimensions of reducing poverty and exclusion" (Wanyama, 2014, p. 59). The research shows that organizing collectively produces social-economic inclusion and the reduction of extreme poverty addressing SDG 1. A favorable, transparent and inclusive policy environment is a precondition to reduce the income gap between waste pickers and other public service providers. 


\subsection{Gender equality (SDG 5)}

Waste picker cooperatives in Brazil attract slightly more women than men. They offer an environment that affirms collective female identities, provides opportunities for personal growth and leadership development, allowing women to value themselves and their category (Ogando et al., 2017). Women are often also the primary caregivers at home, to their children and to the elderly and other family members with health impediments. This research corroborates the finding that cooperatives make an effort to accommodate the double and triple burden many women carry (Dias \& Ogando, 2015).

$54 \%$ of all members in the 21 groups that took part in this research were women. There is a distinct female leadership in organized waste picker organizations. In most cooperatives the administrative positions are primarily composed of women and 12 MBOs had a female president.

Participating in a cooperative or association enables women to become leaders and to develop their skills. The collective work environment and capacity building opportunities that are often created in the cooperative allow them to engage critically in gender related ideas, discuss everyday problems and become involved in political decision making. Many female waste pickers have expressed that to them the cooperative is a space that generates collective consciousness. Gambina and Roffinelli (2013) talk about the general work relations between workers, bosses, employers and the products generated as a process of alienation, in which the employees often feel outside of the job, where they do not see the utility of their work. The self-management (autogestão) and participatory aspect (regular general assemblies) of cooperatives changes the relation to work which empowers women, who are often marginalized in decision making spaces. Those women that have experienced leadership affirmed how important collective working practices are for them. Autonomy and selfdetermination were considered key values to members, driving socio-productive innovations in governance (within the cooperative and with their business relations), in economic issues (diversifying and adding value to their work), and in social aspects (collaboration, solidarity, social justice, empowerment).

The cooperative can also be a space where women 'escape' from the subordinated conditions and where they grow awareness and discuss human rights, domestic violence, and social justice issues. Cooperatives have a potential for creating social assets, particularly if transparency, trust and reliability is encouraged among the members. Cooperative members provide emotional support to others suffering from exclusion, discrimination, violence, substance dependence, sickness or depression (Sentama, 2009) and they support each other financially, as expressed by one of the members: "We had a member going through a situation with a sick son, she needed money to buy medication and food for home. We got together and raised the funds to donate to her".

The collective environment contributes towards gender equality, not just by increasing female membership and providing them with an income, but also by expanding the opportunities for women to build on their agency to empower themselves, to engage in capacity development and life-long learning, as well as by expanding their leadership skills that also help other women. The significant transformations that happen to organized female waste pickers suggests that cooperatives and associations are important drivers for gender equality and that MBOs are able to tackle SDG 5.

\subsection{Building better communities (SDG 11)}

Cities and their surroundings are dense spaces of material consumption and, given the lack of circular material flows, they are also spaces of waste generation and waste accumulation. Particu- larly in low income countries, cities are affected by severe deficiencies in solid waste management, which is often fragmented or absent as a reflection of colonial legacies, creating environmentally hazardous waste accumulation with health implications, especially in informal settlements (Home, 2014). Widespread structural inefficiencies and systemic corruption hinder the transition to more sustainable forms of urban development (Fernández, 2014). In addition, governments are challenged by poverty and high unemployment rates. Often it is the effort of informal and volunteer groups that contribute to community building, making neighborhoods more livable. In many cases these communities end up depending on individual waste pickers, recycling groups, or community-based organizations for cleaning, collection, and recycling services (Gutberlet et al., 2017b; Wilson, Araba, Chinwah \& Cheeseman, 2008).

SDG 11 is about making cities and human settlements inclusive, safe, resilient and sustainable. Adequate waste management, which includes selective waste collection for recycling, is an essential service for community health. Goal 11 specifically targets the reduction of the adverse per capita environmental impact of cities, also by paying special attention to air quality and municipal waste management. This goal puts emphasis not just on the removal and adequate disposal of waste, but also suggests waste reduction, reuse and recycling. According to the International Labor Organization (ILO), cooperatives that are formally established as legal entities are considered part of the formal sector (ILO, 2013) and as formal waste collection, the work of waste picker cooperatives is a critical service for the city. In many parts of the world waste pickers have achieved high levels of organization through worker owned cooperatives (Bhaskar \& Chikarmane, 2012; Dutra et al., 2018; Rutowski \& Rutowski, 2015; Siman et al., 2020). Most waste picker leaders are aware of the multiple services they provide and the responsibilities they have. They participate in skill development, making them more resilient.

To raise awareness, waste pickers frequently speak up at public meetings, in the media (especially social media) and conduct educational campaigns at local schools to explain the work of the cooperative, as was pointed out here: "We know of the importance of our work in terms of the environment, but we are not always recognized in our community where the cooperative is located. We perceive that there is less waste in the streets and less flooding has occurred since we carry out door-to-door collection. We also have created greater job opportunities for those interested in joining the cooperative".

Waste picker cooperatives are important for social inclusion and community building, as they provide low barrier jobs, opportunities for empowerment and leadership development. As expressed by one waste picker: "There are many environmental assets involved in our work: benefits offered to the municipality by the cooperative, such as: social inclusion, ... strengthening/valuing self-esteem, contributing to the quality of life in the municipality and an increase in the life of the landfill". In this study, all research participants confirmed that at least one or more members had been in a situation of vulnerability (e.g. being a single parent, having an addiction problem, having been targeted by violence, suffering a health problem). In all cases the respondents highlighted that the cooperative has helped accommodate such situations; either by helping them find institutional help, accompanying them to appointments, sharing resources to pay for required services or medicine, or by taking the time to listen and speak to the affected member. This was expressed by one of the members: "We already had a worker who had to leave for health reasons, and all Cooperluz members decided to help, and whenever someone is in need, they are helped by the majority". Sometimes their children get sick, requiring the parent to be absent from work. In these cases, the costs derived from the absence of the individual were shared by 
all members or voluntarily by some individuals in the cooperative. Each group develops their own ways of supporting their members.

Stress and anxiety related to income insecurity can be frequent among members. Many cooperatives are not remunerated for the services they provide and rely only on the resale value of the materials, which is often below one Minimum Salary. To address the issue, one of the cooperatives mentioned that they had prioritized their efforts on negotiating a contract with the city, had engaged in collective commercialization and had changed work processes to become more efficient (e.g. reorganizing the work space or introducing appropriate technology). However, not all cooperatives are equally well prepared or are willing to engage in these proactive steps. Some groups recognized that they had no plan to deal with the level of social vulnerability experienced in their cooperative and they felt left alone with these problems, overwhelmed by the scale of the socio-economic and health related challenges.

Working collectively creates a sense of community at the workplace and increases self-esteem, a key ingredient for building citizenship and social inclusion. These characteristics enhance the resilience of waste pickers, reflecting "the degree to which a complex adaptive system is capable of self-organization ... and the degree to which the system can build capacity for learning and adaptation" (Adger, Hughes, Folke, Carpenter, \& Rockström, 2005, p. 1036). Finding adequate strategies by which systems can better address uncertain, new or overpowering stressors is at the forefront of making communities more resilient and sustainable, recognized under SDG 11.

\subsection{Changing consumption and production patterns (SDG 12)}

Urban populations are the main consumers of materials, energy, water and food, and consequently are also an important generator of Greenhouse Gas (GHG) emissions associated with climate change (Satterthwaite, 2009). In a transition away from wastefulness towards resource recovery, ensuring sustainable consumption and production patterns, as aspired in SDG 12, participatory waste management has the potential to address the objectives of a lowcarbon and resource efficient society (Zaman \& Lehmann, 2011, 2013). The principal climate-relevant GHG generated through solid waste includes: methane ( $\mathrm{CH} 4)$, carbon dioxide ( $\mathrm{CO} 2)$, and nitrous oxide (N2O) (Gentil, Christensen, \& Aoustin, 2009). These emissions occur both upstream and downstream of the municipal solid waste management system. Diverting waste towards the circular economy reduces GHG emissions and saves energy (King \& Gutberlet, 2013). The activity performed by waste pickers is a Clean Development Mechanism (CDM), however, it is not recognized (IPEA, \& IBGE, 2004; UNFCCC, 2011). On average, an organized waste picker diverts 2.9 tons of material per month from the waste stream into the circular economy. Some groups were far more productive, diverting up to 10 tons/month/person of material, reflecting the disparity in terms of availability of adequate equipment, logistics, internal governance, membership, and age, among other factors.

The research confirms the role of waste pickers as educators and environmental ambassadors (Baeder, 2009), connecting with households, schools, community centers or companies to speak about their work and the 3Rs (e.g. adequate material separation, minimizing resource losses, differences in recyclability of packaging). They have an impact on society's consumption and disposal patterns, stimulating reduction and better source separation. 13 of the 21 cooperatives verified the regular performance of educational services, while 6 groups were currently not involved in any educational activity in their community. 18 out of the 21 groups actively engaged in public policy discussions. They contributed to the elaboration of municipal waste management plans, and participated in regular meetings of the local environment council (Conselho Municipal de Desenvolvimento do Meio Ambiente - COMDEMA).

Some cooperatives provide education and special collection services for hazardous materials (cooking oil, fluorescent lamps, batteries, etc.), redirecting them towards recovery. These programs could be expanded to include also organic waste. Given the direct access to households, building administrators or businesses, there are further opportunities for waste pickers to build more environmental awareness about the nexus of consumption and waste (Baeder, 2009). Particularly under a greater push for zero waste policies, there is a chance to involve these MBOs in policy design and implementation (Bartl, 2013). Such environmental and socioeconomic outcomes are in line with SDG 12.

\section{Challenges waste picker MBOs encounter when addressing SDGs}

The previous section has highlighted the manifold ways in which organized waste pickers in Brazil already contribute to SDGs. Supportive public policies, funding for infrastructure and capacity building, recognition, and fair remuneration for waste management services are key prerequisites to expand the capacity of waste pickers to address SDGs. Many cooperatives still face innumerous hurdles in their work. Table 3 lists some of the challenges and possible strategies to tackle these.

Waste picker organizations face key structural internal challenges which can prevent them from maximizing their potential to address SDGs. Most of the challenges are of political nature, related to external barriers, enforced by lack of political will and insufficient or inadequate support at the municipal level. Brazil's SSE and resulting specific public policies have been crucial in integrating and strengthening waste picker cooperatives. Their organizations have expanded and their level of organization into networks and a social movement has greatly expanded under previous governments. Support for waste pickers at the municipal level is a paramount condition for them to become the champions in the transition to more sustainable development.

\section{Final considerations}

Solid waste is a visible result of growth-oriented production and consumption and it is a major urban challenge worldwide, creating a myriad of impacts on the environment, oceans, climate, public health, the economy and local communities. There is increasing recognition that continuous growth cannot be reconciled with the environment and that current economic and productive relations as well as identities need to be re-conceptualized away from economic growth and mass consumption-oriented thinking. A shift towards greater community based approaches and grassroots innovations is welcome. A critical perspective on the SDGs uncovers the links between environmental destruction and economic growth, admitting environmental limits and the limitations of technomanagerial fixes to our social, environmental and political problems. This becomes particularly obvious in the context of waste management. A focus on the SDGs through the lens of waste opens new opportunities for urban transitioning towards greater sustainability and for governments to progress on their SDG targets.

Worldwide, waste pickers organize and retrieve recyclable materials for reuse and further industrial processing. These groups re-imagine their production and economic activities in terms other than those made available by capitalism. Their everyday actions, despite lived contradictions, reclaim citizenship and produce democratic spaces centered on solidarity and the care of others. The collective practices of recycling cooperatives generate social, economic and environmental benefits which are not yet widely 
Table 3

Key actions, challenges and strategies applied by waste picker organizations to address SDGs.

\begin{tabular}{|c|c|c|c|c|c|}
\hline SDG & SDG Theme & Current local context & Actions that affect SDGs & Challenges & Strategies to overcome \\
\hline Goal 1 & No Poverty & $\begin{array}{l}\text { High unemployment particularly } \\
\text { among youth and elderly. } \\
\text { Few opportunities for unskilled } \\
\text { workers. }\end{array}$ & $\begin{array}{l}\text { Active hiring of new } \\
\text { members. } \\
\text { Low entry barriers for } \\
\text { individuals who are often } \\
\text { socially excluded because } \\
\text { of race, age, gender, } \\
\text { disability, health issues, or } \\
\text { criminal record. } \\
\text { Opportunities for capacity } \\
\text { building and skill } \\
\text { development to expand } \\
\text { income opportunities. } \\
\text { Collective } \\
\text { commercialization, service } \\
\text { contracts to obtain higher } \\
\text { income levels. }\end{array}$ & $\begin{array}{l}\text { Lack of official social assistance } \\
\text { to support socially/economically } \\
\text { challenged individuals. } \\
\text { Lack of preparedness of Member- } \\
\text { Based Organizations (MBOs) to } \\
\text { deal with complicated } \\
\text { psychological issues affecting } \\
\text { one or more members. } \\
\text { Neglect, no government support } \\
\text { and lack of recognition. } \\
\text { No service contracts. } \\
\text { Structural problems within the } \\
\text { cooperative. }\end{array}$ & $\begin{array}{l}\text { Active participation in public } \\
\text { policy making through council } \\
\text { meetings. } \\
\text { Persistence in negotiating with } \\
\text { government and business for } \\
\text { service contracts and to } \\
\text { participate in reverse logistics } \\
\text { programs. } \\
\text { Networking and liaison with } \\
\text { other MBOs, networks and } \\
\text { partners. } \\
\text { Social and Solidarity Economy. } \\
\text { Better control by members, } \\
\text { transparency and democratic } \\
\text { decision making }\end{array}$ \\
\hline Goal 5 & $\begin{array}{l}\text { Gender } \\
\text { Equality }\end{array}$ & $\begin{array}{l}\text { Lack of equitable job } \\
\text { opportunities for women, } \\
\text { particularly single mothers or } \\
\text { elderly. }\end{array}$ & $\begin{array}{l}\text { Gender inclusive } \\
\text { environment. } \\
\text { Equal opportunities at the } \\
\text { workplace. } \\
\text { Equal opportunity for } \\
\text { human development } \\
\text { offered through the MBO. } \\
\text { Supporting women } \\
\text { leadership building. } \\
\text { Flexible and solidary } \\
\text { approach accommodating } \\
\text { child care or health specific } \\
\text { needs. }\end{array}$ & $\begin{array}{l}\text { The results of the colonial and } \\
\text { patriarchal social system } \\
\text { dominant in Brazil justifies } \\
\text { gender inequality, subjugating } \\
\text { women. } \\
\text { These barriers are difficult to } \\
\text { break and sometimes also } \\
\text { manifest in MBOs. }\end{array}$ & $\begin{array}{l}\text { Capacity building and } \\
\text { educational opportunities } \\
\text { expand the horizon of the } \\
\text { participants, gradually leading } \\
\text { to transformative change. } \\
\text { Support from the secretariat of } \\
\text { women recyclers of the } \\
\text { national waste pickers' } \\
\text { movement (MNCR) }\end{array}$ \\
\hline Goal 8 & $\begin{array}{l}\text { Decent Work } \\
\text { and } \\
\text { Economic } \\
\text { Growth }\end{array}$ & $\begin{array}{l}\text { Few low barrier opportunities for } \\
\text { decent work Decent work is a } \\
\text { particularly difficult } \\
\text { achievement for those that are } \\
\text { marginalized and stigmatized. }\end{array}$ & $\begin{array}{l}\text { The MBO offers: regulated } \\
\text { working and rest hours, } \\
\text { holidays, sick leave, } \\
\text { maternity leave, } \\
\text { retirement pay and other } \\
\text { social and health benefits. } \\
\text { Access to washrooms, } \\
\text { running water, kitchen or } \\
\text { refectory. } \\
\text { Personal Protective } \\
\text { Equipment. (PPE) } \\
\text { Continuous opportunities } \\
\text { for skill development. }\end{array}$ & $\begin{array}{l}\text { Economic instability and price } \\
\text { fluctuations. } \\
\text { Difficulties in collective } \\
\text { commercialization and } \\
\text { dependency on middlemen. } \\
\text { Lack of resources to buy PPE } \\
\text { Serious ergonomic and } \\
\text { occupational health problems. } \\
\text { Lack of resources and/or } \\
\text { governmental support to address } \\
\text { workers health and safety issues. } \\
\text { Lack of commitment from } \\
\text { governments to honour service } \\
\text { contracts and remuneration } \\
\text { bylaws (e.g. in Diadema, the city } \\
\text { which first remunerated waste } \\
\text { pickers and is now omissive). } \\
\text { Structural economic forces and } \\
\text { cultural principles based on } \\
\text { oppression, exclusion and } \\
\text { exposure to human and } \\
\text { environmental harm as core } \\
\text { drivers of decent work deficits. }\end{array}$ & $\begin{array}{l}\text { Working conditions in MBOs } \\
\text { can be improved, with the } \\
\text { introduction of better } \\
\text { equipment and ergonometric } \\
\text { adjustments. } \\
\text { Skill development. } \\
\text { Risk prevention training. } \\
\text { Networking and participation } \\
\text { in waste picker networks } \\
\text { (MNCR, international alliances } \\
\text { such as GlobalRec, RedLacre, } \\
\text { WIEGO, NoBurn) } \\
\text { Political mobilization to defend } \\
\text { the category of waste pickers. } \\
\text { National Waste Management } \\
\text { Law and its repeated reference } \\
\text { to waste pickers as key } \\
\text { protagonists (PNRS). } \\
\text { Participatory governance. }\end{array}$ \\
\hline Goal 11 & $\begin{array}{l}\text { Sustainable } \\
\text { Cities and } \\
\text { Communities }\end{array}$ & $\begin{array}{l}\text { Lack of official recycling } \\
\text { programs (only } 20 \% \text { of Brazilian } \\
\text { cities have an official program) } \\
\text { and insufficient recycling rates in } \\
\text { most cities (only } 3.5 \% \text { of the } \\
\text { waste generated is officially } \\
\text { recycled in Brazil) Fracalanza } \\
\text { and Besen (2016). } \\
\text { Most resource recovery still } \\
\text { happens through the informal } \\
\text { waste picker sector. }\end{array}$ & $\begin{array}{l}\text { Separate waste collection } \\
\text { services increase diversion } \\
\text { rates into the circular } \\
\text { economy, reduce the risk of } \\
\text { water logging and flooding } \\
\text { Educational services, } \\
\text { informing communities, } \\
\text { businesses, schools about } \\
\text { the 3Rs and the work of } \\
\text { waste pickers. } \\
\text { The work of waste pickers } \\
\text { reduces GHG emissions } \\
\text { and energy use. } \\
\text { Resource recovery reduces } \\
\text { the pressure on natural } \\
\text { resources. }\end{array}$ & $\begin{array}{l}\text { Privatisation of waste } \\
\text { management, creating less } \\
\text { opportunities for MBOs (door-to- } \\
\text { door collection). } \\
\text { Inadequate technology (e.g. } \\
\text { compactor truck crushes all } \\
\text { recyclables including glass, thus } \\
\text { creating risks and health } \\
\text { hazards). } \\
\text { Neglect and lack of commitment } \\
\text { by the local government. } \\
\text { Lack of dialogue local } \\
\text { government and MBOs. } \\
\text { Low quality source separation. } \\
\text { High levels of rejected materials } \\
\text { at MBOs. }\end{array}$ & $\begin{array}{l}\text { Continuous dialogue and } \\
\text { negotiation with the } \\
\text { government. } \\
\text { Environmental education } \\
\text { initiatives. } \\
\text { Media communication and } \\
\text { outreach. } \\
\text { Partnerships with NGOs and } \\
\text { universities. } \\
\text { Skill development for waste } \\
\text { pickers }\end{array}$ \\
\hline Goal 12 & $\begin{array}{l}\text { Responsible } \\
\text { Production } \\
\text { and } \\
\text { Consumption }\end{array}$ & $\begin{array}{l}\text { Low level of awareness among } \\
\text { society about responsible } \\
\text { consumption and adequate } \\
\text { waste separation. } \\
\text { No organic waste collection. } \\
\text { Stigma and undervalued }\end{array}$ & $\begin{array}{l}\text { MBOs educate the public } \\
\text { on the 3Rs through door- } \\
\text { to-door collection, } \\
\text { engagement at schools, } \\
\text { universities or businesses. } \\
\text { Participation in regional }\end{array}$ & $\begin{array}{l}\text { Lack of funding to become more } \\
\text { engaged in education and } \\
\text { outreach. } \\
\text { Mainstream advertisement } \\
\text { incentivizes irresponsible } \\
\text { consumption and goes against }\end{array}$ & $\begin{array}{l}\text { Engagement in the local, } \\
\text { regional, federal and } \\
\text { international waste pickers } \\
\text { movement. } \\
\text { Collection of alternative } \\
\text { recyclable materials (e.g. }\end{array}$ \\
\hline
\end{tabular}


Table 3 (continued)

\begin{tabular}{|c|c|c|c|c|c|}
\hline SDG & SDG Theme & Current local context & Actions that affect SDGs & Challenges & Strategies to overcome \\
\hline & & $\begin{array}{l}\text { perception of waste pickers by } \\
\text { the general public. }\end{array}$ & $\begin{array}{l}\text { and national waste pickers } \\
\text { movement. } \\
\text { Participation in } \\
\text { conferences, workshops } \\
\text { and seminars. } \\
\text { Production of videos/art } \\
\text { projects. } \\
\text { Dissemination of } \\
\text { environmental education } \\
\text { materials on 3Rs. } \\
\text { Exchange on best recycling } \\
\text { practices and reverse } \\
\text { logistics. }\end{array}$ & $\begin{array}{l}\text { the messages spread by waste } \\
\text { pickers. }\end{array}$ & $\begin{array}{l}\text { cooking oil, fluorescent lamps, } \\
\text { wood, textiles) and } \\
\text { development of appropriate } \\
\text { technology for recycling, reuse } \\
\text { or repurposing. }\end{array}$ \\
\hline
\end{tabular}

recognized as such. Most waste pickers are not fairly remunerated for the social and environmental services they provide. Government arrangements created for the co-production in waste management require participatory and long-term relationships (Gutberlet et al., 2016; Joshi \& Moore, 2004; Moretto et al., 2018), based on democratic policy and legal frameworks for inclusion (Aparcana, 2017).

The article has discussed different social, economic and environmental roles waste picker organizations play when involved in waste management. The research results and theoretical discussions provide insights to some of the social and environmental responsibilities these groups have in fighting injustices. Their struggles center on reducing poverty, improving working conditions, reducing environmental degradation and resource extraction, and mitigating climate change. Supportive national public policies, particularly under the SSE have facilitated the organization and strengthening of waste picker cooperatives in Brazil over the past two decades, until 2018. However, a dangerous dismantling of the institutions and policies related to the SSE, under the current hyper neoliberal government, uncovers the vulnerable conditions under which organized waste pickers still operate. They are doing their best, but they require other actors, specifically local governments, to support their work.

The Brazilian experience has demonstrated that public policies in favor of the socio-productive inclusion of organized waste pickers in waste governance is crucial in order to develop their full potential in promoting sustainable consumption and production patterns. Inviting organized waste pickers as local waste management actors to the negotiation table to plan and implement partnerships is a basic requirement for participatory waste governance. This means recognizing the skills and knowledge waste pickers have developed related to resource recovery, reuse and recycling. It also means to remunerate the social and environmental services they provide to the city and their communities. An inclusive political agenda on waste management will not only provide more opportunities to achieve the ILO's proposed seven essential securities necessary for decent work, but will also expand the potential to address several other SDGs, including: poverty reduction, gender equality, inclusive, safe, resilient and sustainable cities and human settlements, as well as sustainable consumption and production patterns. It should be the highest priority of policy makers to transition towards inclusive forms of waste management, to create spaces to negotiate contracts with these organizations and to pay a fair price for the services of collection and separation of recyclables among other tasks waste pickers are able to perform.

\section{Declaration of Competing Interest}

The authors declare that they have no known competing financial interests or personal relationships that could have appeared to influence the work reported in this paper.

\section{Acknowledgements}

This research was funded by the Social Sciences and Humanities Council in Canada (SSHRC) (Grant file number 890-2016-0098), by the Swedish Research Council (Grant numbers: 2016-06289) and by the Funding Agency of the State of São Paulo FAPESP, Brazil under the project: Environmental Governance in the São Paulo Macrometropolis, Process No. 2015/03804-9.

My gratitude goes to all waste picker participants who have cogenerated the knowledge presented in this article with me and to Solange Dias, the research assistant who participated in the study. I would also like to acknowledge the constructive comments and suggestions provided by the Journal Editor Dr. Arun Agrawal, as well as the anonymous peer reviewers, whose input has helped me to improve the paper.

\section{References}

Adger, W. N., Hughes, T. P., Folke, C., Carpenter, S. R., \& Rockström, J. (2005). Socialecological resilience to coastal disasters. Science, 309(5737), 1036-1039.

Aparcana, S. (2017). Approaches to formalization of the informal waste sector into municipal solid waste management systems in low- and middle-income countries: Review of barriers and success factors. Waste Management, 61, 593-607.

Baeder, A. M. (2009). Educação Ambiental e Mobilização Social: Formação de Catadores na Grande São Paulo. São Paulo: Faculdade de Educação da Universidade de São Paulo (Doctoral Thesis).

Bartl, A. (2013). Barriers towards achieving a zero-waste society. Waste Management, 31(12), 2369-2370.

Besen, G. R., Ribeiro, H., Gunther, W. M. R., \& Jacobi, P. R. (2014). Selective waste collection in the São Paulo metropolitan region: Impacts of the national solid waste policy. Ambiente \&' Sociedade, 17(3), 253-272.

Bhaskar, A., \& Chikarmane, P. (2012). The story of waste and its reclaimers: Organising waste collectors for better lives and livelihoods. The Indian Journal of Labour Economics, 55(4), 595-619.

Binion, E., \& Gutberlet, J. (2012). The effects of handling solid waste on the wellbeing of informal and organized recyclers: A review of the literature. Journal of Occupational and Environmental Health, 18(1), 43-52.

Brazil (2007). Política Nacional de Saneamento Básico, Lei 11.445. Diário Oficial da República Federativa do Brasil, Brasília, DF, 05 jan. 2007. <http:/ www.planalto.gov.br/ccivil_03/_ato2007-2010/2007/lei/111445.htm>.

Brazil. (2010). Política Nacional de Resíduos Sólidos, Lei 12.305. Diário Oficial da República Federativa do Brasil, Brasília, DF, 2 ago. 2010. <http:// www.planalto.gov.br/ccivil_03/_ato2007-2010/2010/lei/112305.htm>.

Britschgy, L. F. C. (2018). Economia solidária e catadores(as) de materiais recicláveis: análise das ações e políticas públicas em Rio Claro- SP no período de 2009 à 2018

Caruana, M., \& Srnec, C. (2013). Public policies addressed to the social and solidarity economy in South America. Toward a new model? VOLUNTAS: International Journal of Voluntary and Nonprofit Organizations, 24(3), 713-732.

Carvalho, A. M. R., \& Rodini, C. A. (2017). Perfil socioprofissional de catadoras e catadores em associaç̃̃es e cooperativas do Oeste Paulista. In A. R. Souza \& M. Zanin (Org.) (Eds.), A economia solidária e os desafios globais do trabalho. São Carlos: EdUFSCar.

Clement, V. (2019). Beyond the sham of the emancipatory Enlightenment: Rethinking the relationship of Indigenous epistemologies, knowledges, and geography through decolonizing paths. Progress in Human Geography., 43(2), 276-294. https://doi.org/10.1177/0309132517747315.

Conselho Nacional de Economia Solidária. (2015). 1o Plano Nacional de Economia Solidária (2015- 2019). Brasília. <http://trabalho.gov.br/trabalhador-economiasolidaria/plano-nacional-de-economia-solidaria>. 
Dagnino, R. D. S., \& Johansen, I. C. (2017). Os catadores no Brasil: características demográficas e socioeconômicas dos coletores de material reciclável, classificadores de resíduos e varredores a partir do censo demográfico de 2010. Mercado de Trabalho, 62, 115-125.

Demaria, F., \& Schindler, S. (2016). Contesting urban metabolism: Struggles over waste-to-energy in Delhi, India. Antipode, 48, 293-313.

Dias, S., \& Samson, M. (2016). Informal Economy Monitoring Study Sector Report: Waste Pickers. Cambridge, MA, USA: WIEGO.

Dias, S., \& Ogando, A. (2015). Rethinking gender and waste: Exploratory finding from participatory action research in Brazil. Work organization, Labour \& Globalisation, $9(2), \quad 51-63 \quad$ https://www.jstor.org/stable/10. 13169/workorgalaboglob.9.2.0051.

Dias, S. M. (2002). Construindo a cidadania: avanços e limites do Projeto de Coleta Seletiva em parceria com a ASMARE. Belo Horizonte: Instituto de Geociências, Department of Geography, Universidade Federal de Minas Gerais (Masters Thesis).

Dutra, R. M. de S., Yamane, L. H., \& Siman, R. R. (2018). Influence of the expansion of the selective collection in the sorting infrastructure of waste pickers' organizations : A case study of 16 Brazilian cities. Waste Management, 77, 50-58. https://doi.org/10.1016/j.wasman.2018.05.009.

Economic Commission for Latin America and the Caribbean (ECLAC) and International Labour Organization (ILO). (2012). The employment situation in Latin America and the Caribbean. Oct. 2012, (7): 27 pp. <https:// repositorio.cepal.org/bitstream/handle/11362/37582/ECLAC-ILO-Bulletin7_en. pdf;jsessionid=D6F313C916322E432D02CC29F84EE6CE? sequence=1>.

Ezeah, C., Fazakerley, J. A., \& Roberts, C. L. (2013). Emerging trends in informal sector recycling in developing and transition countries. Waste Management, 33(11), 2509-2519. https://doi.org/10.1016/j.wasman.2013.06.020.

EMPLASA (2018). (Empresa Paulistade Planejamento Metropolitano SA) Website: https://emplasa.sp.gov.br/RMSP.

Fahmi, W., \& Sutton, K. (2010). Cairo's contested garbage: Sustainable solid waste management and the Zabbaleen's Right to the City. Sustainability, 2, 1765-1783. https://doi.org/10.3390/su2061765.

Fracalanza, A. P., \& Besen, G. R. (2016). Challenges for the sustainable management of municipal solid waste in Brazil. DISP 205, 53(2), 49-55.

Felipone, S. M. N. (2010) Análise da Implementação da lei e dos princípios do Cooperativismo: o caso de uma cooperativa de produção, coleta, triagem, beneficiamento e comercialização de materiais recicláveis da cidade de São Paulo (Analysis of the Implementation of the Law and Principles of the Cooperative Movement: the Case of a Cooperative of Production, Collection, Sorting, Processing and Marketing of Recyclable Materials from the City of São Paulo). Masters Thesis, Centro Universitário Senac, São Paulo, Brazil, October 2010.

Fernández, J. E. (2014) Urban metabolism of the global south. In: Parnell, S. \& Oldfield, S. (Eds.) The Routledge Handbook on Cities of the Global South. Abingdon and New York: Routledge. pp. 597-612.

Gago, V. (2017). Neoliberalism from Below: Popular pragmatics and baroque economies. Durham: Duke University Press.

Gambina, J., \& Roffinelli, G. (2013). Building alternatives beyond capitalism. In C. Piñeiro Harnecker (Ed.), Cooperatives and Socialism, A View from Cuba (pp. 46-59). New York: Palgrave Macmillan.

Gentil, E., Christensen, T. H., \& Aoustin, E. (2009). Greenhouse gas accounting and waste management. Waste Management E' Research, 27(8), 696-706.

Gerometta, J., Haussermann, H., \& Longo, G. (2005). Social innovation and civil society in urban governance: Strategies for an inclusive city. Urban Studies, 42 (11), 2007-2021.

Gupta, J., \& Vegelin, C. (2016). Sustainable development goals and inclusive development. International Environmental Agreements, 16, 433-448.

Gutberlet, J., Bramryd, T., \& Johansson, M. (2020). Expansion of the Waste-based commodity frontier: Insights from Sweden and Brazil. Sustainability, 12, 2628. https://doi.org/10.3390/su12072628.

Gutberlet, J., \& Uddin, S. M. N. (2018). Household waste and health risks affecting waste pickers and the environment in low- and middle-income countries. International Journal of Occupational and Environmental Health, 23(6), 1-12. https://doi.org/10.1080/10773525.2018.1484996.

Gutberlet, J., Carenzo, S., Kain, J.-H., \& de Azevedo, A. M. M. (2017a). Waste picker organizations and their contribution to the circular economy: Two case studies from a global south perspective. Resources, 6(52), 1-12 http://www.mdpi.com/ 2079-9276/6/4/52/pdf.

Gutberlet, J., Kain, J.-H., Nyakinya, B., Oloko, M., Zapata, P., \& Zapata Campos, M. J. (2017b). Bridging weak links of solid waste management in informal settlements. The Journal of Environment \& Development., 26(1), 106-131. https://doi.org/10.1177/1070496516672263.

Gutberlet, J., Kain, J.-H., Nyakinda, B., Oshieng, D. H., Odhiambo, N., Oloko, M., ... Zapata Campos, M. J. (2016). Socio-environmental entrepreneurship and the provision of critical services in informal settlements. Environment and Urbanization, 28, 205-222. https://doi.org/10.1177/0956247815623772.

Gutberlet, J. (2015). Cooperative urban mining in Brazil: Collective practices in selective household waste collection and recycling. Waste Management., 45, 22-31. https://doi.org/10.1016/j.wasman.2015.06.023.

Harvey, D. (2004). The 'New' Imperialism: Accumulation by Dispossession Socialist Register, 40. <https://socialistregister.com/index.php/srv/article/view/5811>.

Home, R. (2014) Shaping cities of the global south. In: Parnell, S. \& Oldfield, S. (Eds.) The Routledge Handbook on Cities of the Global South. Abingdon and New York: Routledge. pp. 75-85.
Howard, H. A. (2016). Co-Producing community and knowledge: Indigenous epistemologies of engaged, ethical research in an urban context. Engaged Scholar Journal, 2(1), 205-224. https://doi.org/10.15402/esj.v2i1.207.

Hutchinson, A., \& Lovell, A. (2013). Participatory action research: Moving beyond the mental health "service user' identity. Journal of Psychiatric and Mental Health Nursing, 20(7), 641-649. https://doi.org/10.1111/jpm.12001.

IBGE (Instituto Brasileiro de Geografia e Estatística) (2009). Pesquisa Nacional por Amostra de Domicílios 2009. Rio de Janeiro: IBGE.

IBGE (2012). Pesquisa Nacional por Amostra de Domicílio 2012. Rio de Janeiro: IBGE.

ILO (International Labour Organization (2019). Waste pickers' cooperatives and social and solidarity economy organizations. In Cooperatives and the world of work No. 12 (pp. 5). Geneva: International Labour Office.

ILO (International Labour Organization) (2018). World employment social Outlook. Trends 2018. Geneva: International Labour Office.

ILO (International Labour Organization) (2013). The informal economy and decent work: A policy resource guide supporting transitions to formality. International Labour Office, Employment Policy Department, Geneva, International Labour Office.

ILO (International Labour Organization) (2012). Promoting safety and health in a green economy. Geneva International Labour Organization.

ILO (International Labour Organization) (2008). Toolkit for mainstreaming employment and decent work - Country level application. United Nations System Chief Executives Board for Coordination. Geneva: , International Labour Office.

ILO (International Labour Organization) (2002). Decent Work and the Informal Economy. Geneva: ILO Publications.

International Co-operative Alliance. (2018). World Co-operative Monitor_2017_EN. Retrieved from: <https://www.ica.coop/en/cooperatives/what-is-acooperative>.

IPEA (Instituto de Pesquisa Economica Aplicada). (2020). Atlas da Violência. IPEA \& Forum Brasileiro da Segurança Publica. <https://www.ipea.gov.br/ atlasviolencia/>.

IPEA (Instituto de Pesquisa Economica Aplicada) (2013). In Situação Social das Catadoras e dos Catadores de Material Reciclável e Reutilizável, Brazil (pp. 68). Brasilia: IPEA.

IPEA (Instituto de Pesquisa Economica Aplicada) \& IBGE (Instituto Nacional de Geografia e Estatística) (2004). Millennium Development Goals: Brazilian Monitoring Report. Brasília: IPEA \& IBGE.

Jacobi, P. R., \& Dias Perez, U. (2016). Urban environmental management and governance challenges for the 21st century. DISP 205, 52(2), 26-34. https://doi. org/10.1080/02513625.2016.1195580.

Jaligot, R., Wilson, D. C., Cheeseman, C. R., Shaker, B., \& Stretz, J. (2016). Applying value chain analysis to informal sector recycling: A case study of the Zabaleen. Resources, Conservation and Recycling, 114, 80-91.

Joshi, A., \& Moore, M. (2004). Institutionalised co-production: Unorthodox public service delivery in challenging environments. Journal of Development Studies, 40 (4), 31-49. https://doi.org/10.1080/00220380410001673184.

Kaza, L., Yao, L., Bhada-Tata, P., \& Woerden, V. (2018). What a Waste 2.0: A Global Snapshot of Solid Waste Management to 2050. Urban Development Series. Washington: The World Bank.

King, M., \& Gutberlet, J. (2013). Contribution of cooperative sector recycling to greenhouse gas emissions reduction: A case study of Ribeirão Pires, Brazil. Waste Management, 33(12), 2771-2780.

Kovach, M. (2009). Indigenous methodologies: Characteristics, conversations, and contexts. Toronto: University of Toronto Press.

Laville, J.-L. (2013). The Social and Solidarity Economy. A Theoretical and Plural Framework. Draft paper prepared for the UNRISD Conference Potential and Limits of Social and Solidarity Economy 6-8 May 2013, Geneva, Switzerland. <https://www.unrisd.org/80256B3C005BCCF9/httpNetITFramePDF?ReadForm\& parentunid=228DBE3C0DE3D2D3C1257B5F00699C58\&parentdoctype=paper\& netitpath=80256B3C005BCCF9/(httpAuxPages)/228DBE3C0DE3D2D3C1257B5 F00699C58/\$file/Jean-Louis Laville.pdf>.

Le Blanc, D. (2015). Towards integration at last? The sustainable development goals as a network of targets. Sustainable Development, 23(3). https://doi.org/10.1002/ sd.1582.

Luckin, D., \& Sharp, L. (2004). Remaking local governance through community participation? The case of the UK Community waste sector. Urban Studies, 41(8), 1485-1505.

Marques, J. S. (2014) Social and Solidarity Economy Between Emancipation and Reproduction. UNRISD (United Nations Research Institute for Social Development), Occasional Paper 2: Potential and Limits of Social and Solidarity Economy.

Meira, R., Dutra, D. S., Yamane, L. H., \& Siman, R. R. (2020). Influence of the expansion of the selective collection in the sorting infrastructure of waste pickers 'organizations : A case study of 16 Brazilian cities. Waste Management, 77, 50-58. https://doi.org/10.1016/j.wasman.2018.05.009.

Melamed, J. (2015). Racial capitalism. Critical Ethnic Studies, 1, 76-85.

Mitlin, D. (2008). With and beyond the state - coproduction as a route to political influence, power and transformation for grassroots organizations. Environment and Urbanization, 20(2), 339-360.

MNCR (Movimento Nacional dos Catadores de Materiais Recicláveis). (2012). Declaração de princípios e objetivos do MNCR. Access: <www.mncr.org.br/>

Moretto, L., Faldi, G., Ranzato, M., Rosati, F. N., \& Boozi, J. I. (2018). Challenges of water and sanitation service co-production in the global South. Environment and Urbanization, 30(4), 425-443. https://doi.org/10.1177/0956247818790652. 
Moser, C. (1978). Informal sector or petty commodity production: Dualism or dependence in urban development? World Development, 6, 1041-1064.

Moulaert, F., \& Nussbaumer, J. (2005). Defining the social economy and its governance at the neighbourhood level: A Methodological reflection. Urban Studies, 42(11), 2071-2088.

Moulaert, F., \& Ailenei, O. (2005). Social economy, third sector and solidarity relations: A conceptual synthesis from history to present. Urban Studies, 42(11), 2037-2053.

Murakami, F., Sulzbach, A., Pereira, G. M., Borchardt, M., \& Sellitto, M. A. (2015). How the Brazilian government can use public policies to induce recycling and still save money? Journal of Cleaner Production, 96, 94-101. https://doi.org/ 10.1016/j.jclepro.2014.03.083.

Nzeadibe, T. C. (2015). Moving up the hierarchy: involving the informal sector to increase recycling rates in Nigerian cities. In R. Mohee \& T. Simelane (Eds.), Future directions of solid waste management in Africa (1st ed., pp. 73-90). Africa Institute of South Africa.

Ogando, A. C., Roever, S., \& Rogan, M. (2017). Gender and informal livelihoods: Coping strategies and perceptions of waste pickers in Sub-Saharan Africa and Latin America. International Journal of Sociology \& Social Policy, 37, 435-451.

O'Hare, P. (2020). 'We looked after people better when we were informal': The 'QuasiFormalisation' of Montevideo's waste-pickers. Bulletin of Latin American Research, 39, 53-68.

Oliveira Dias, M. de (2019). Current facts on Brazilian cooperative societies. Global Scientific Journals, 7(9), 624-633. Online: ISSN 2320-9186.

Omotoso, K. O. (2017). Informal waste recycling activities: Implications for livelihood and health. African Journal of Science, Technology, Innovation and Development, 9(6), 785-793. https://doi.org/10.1080/20421338.2017.1380584.

Pulido, L. (2017). Geographies of race and ethnicity II: Environmental racism, racial capitalism and state-sanctioned violence. Progress in Human Geography, 41, 524-533.

Randolph, R., \& Frey, K. (2019). Planning and governance: Towards radical political approaches. In A. Eraydin \& K. Frey (Eds.), Politics and conflict in governance and planning (pp. 38-55). New York: Routledge.

Rossi, F. C. R. (2018). A atuação do Movimento Nacional de Catadores de Materiais Recicláveis (MNCR) na construção de políticas públicas para catadores nos governos do PT no âmbito federal. In: Anais do $42^{\circ}$ Encontro Anual da Anpocs, 22 - 26 Oct. 2018, Caxambu - MG.

Routh, S. (2014). Enhancing capabilities through labour law: Informal workers in India. New York: Routledge.

Rutowski, J. E., \& Rutowski, E. W. (2015). Expanding worldwide urban solid waste recycling: The Brazilian social technology in waste pickers inclusion. Waste Management \& Research, 33(12), 1084-1093.

Samson, M. (2015). Accumulation by dispossession and the informal economy: Struggles over knowledge, being and waste at a Soweto garbage dump. Environment and Planning D: Society and Space, 33(5), 813-830.

Siman, R. R., Yamane, L. H., Baldam, R. de L., Tackla, J. P., Lessa, S. F. de A., \& Britto, P. M. de (2020). Governance tools: Improving the circular economy through the promotion of the economic sustainability of waste picker organizations. Waste Management, 105, 148-169. https://doi.org/10.1016/j.wasman.2020.01.040.
Satterthwaite, D. (2009). The implications of population growth and urbanization for climate change. Environment and Urbanization, 21(2), 545-567.

Schiochet, V. (2012). A experiência da Secretaria Nacional de Economia Solidária: um breve relato. In S. Lianza \& F. C. Henriques (Org.) (Eds.), A economia solidária na América Latina: Realidades Nacionais e Políticas Públicas. Rio de Janeiro: Pró Reitoria de Extensão UFRJ.

Schreier, M. (2012). Qualitative content analysis in practice. Los Angeles, London: SAGE.

Sentama, W. (2009). Peacebuilding in post-genocide Rwanda: The role of co-operatives in the restoration of interpersonal relationships. Gothenburg University: School of Global Studies (PhD Thesis).

Silva, R. F., \& Carvalho Filho, M. V. (2018). Território e economia solidária: relações relevantes para a construção do desenvolvimento sustentável. In Mercado de trabalho (pp. 153-161). IPEA.

Strand, K., Marullo, S., Cutforth, N., Stoeker, R., \& Donohue, P. (2003). CommunityBased Research and Higher Education: Principles and Practices. San Francisco, CA: Jossey-Bass.

Terraza, H. \& Sturzenegger, G. (2010). Dinámicas de organización de los Recicladores informales: tres casos de estudio en América Latina, Banco Interamericano de Desarrollo, Sector de Infraestructura y Medio Ambiente. Nota Técnica No. 117. <http://idbdocs.iadb.org/wsdocs/getdocument. aspx?docnum=35325785>.

Tucker, K., \& Anantharaman, M. (2020). Informal work and sustainable cities: From formalization to reparation. One Earth.

UNFCCC (United Nations Framework Convention on Climate Change). (2011). AMSIII. Recovery and Recycling of Materials from Solid Wastes - Version 3.0. UNFCCC. $<$ http://cdm.unfccc.int/methodologies/DB I09S4G8NFK11QYSD409FTGM18K9NYK>.

Utting, P. (2017). Public policies for social and solidarity economy. International Labour Organization (ILO). Geneva: ILO.

Wanyama, F. O. (2014). Cooperatives and the Sustainable Development Goals: A contribution to the post-2015 development debate. Geneva: ILO.

Weber, H. (2017). Politics of 'Leaving No One Behind': Contesting the 2030 sustainable development goals Agenda. Globalizations, 14, 399-414.

Wilson, D., Rodic, L., Scheinberg, A., Velis, C. A., \& Alabaster, G. (2012). Comparative analysis of solid waste management in 20 cities. Waste Management $\mathcal{E}$ Research, 30(3), 237-254. https://doi.org/10.1177/0734242X12437569.

Waiselfisz, J. J. (2012). Mapa da Violência: A cor dos homicídios no Brasil. Rio de Janeiro: CEBELA, FLACSO; Brasília: Secretaría de Políticas de Promoção da Igualdade Racial da Presidencia da República/Paraná (SEPPIR/PR). <https:// www.mapadaviolencia.org.br/pdf2012/mapa2012_cor.pdf>.

Wilson, D. C., Araba, A., Chinwah, K., \& Cheeseman, C. (2008). Building recycling rates through the informal sector. Waste Management, 29, 629-635.

Zaman, A. U., \& Lehmann, S. (2011). Urban growth and waste management optimization towards 'zero waste city'. City, Culture and Society, 2(4), $177-187$.

Zaman, A. U., \& Lehmann, S. (2013). The zero-waste index: A performance measurement tool for waste management systems in a 'zero waste city'. Journal of Cleaner Production, 50(1), 123-132. 